\title{
EFFECT OF TINOSPORA CORDIFOLIA IN CHRONIC BRONCHITIS PATIENTS
}

\author{
Abdul Hannan', Shyamal Sinha², Rashmi Sinha33, Ganesh Kanchan ${ }^{4}$
}

${ }^{1}$ Assistant Professor, Department of Pharmacology, Grant Government Medical College, Mumbai. ${ }^{2}$ Assistant Professor, Department of Pharmacology, Grant Government Medical College, Mumbai. ${ }^{3}$ Assistant Professor, Department of Pharmacology, Grant Government Medical College, Mumbai. ${ }^{4}$ Resident, Department of Pharmacology, Grant Government Medical College, Mumbai.

ABSTRACT

\section{BACKGROUND}

Chronic obstructive pulmonary disease is one of the common problem affecting $10 \%$ of population above the age of 45 years in the world, associated with frequent acute medical admissions to hospital. One of the factor contributing in incidences of repeated infections is suppressed immune response by host. The depression of immune system is characterised by a reduction in the number and phagocytic function of neutrophils and macrophages as well as a reduction in the intracellular bactericidal capacity of these cells. The T-cell function is also diminished. The potential of Indian medicinal plants to be useful as immunostimulants appears encouraging. Ayurveda, the Indian traditional system of medicine, lays emphasis on promotion of health a similar concept to strengthening host defense against different diseases. These plants are labelled as 'Rasayanas,' Tinospora cordifolia is one of them. Present study was undertaken by Department of Pharmacology, Clinical Division, Govt. Medical College and Hospital, Aurangabad to evaluate.

\section{MATERIALS AND METHODS}

Present study was randomised, single blind, placebo controlled study. A total of 60 patients were enrolled in the study, divided into two groups of 30 each. Number of episodes of acute exacerbations in previous two months were recorded. Chief complaints and history regarding present illness was asked. The severity of symptoms present at the time of enrollment was recorded independently in respect of each patient on a four-point scale (Absent, mild, moderate and severe). Film coated Tinospora cordifolia tablet contains $500 \mathrm{mg}$ of active ingredient were provided to each patient of test group and identical looking placebo tablets to each patient of placebo group.

\section{RESULTS}

There is statistically significant $(\mathrm{P}<0.05)$ increase in percentage of predicted values of $\mathrm{FEV}_{1}$ and Peak Expiratory Flow in test group as compared to Placebo group. There was statistically significant $(\mathrm{P}<0.05)$ reduction in episodes of acute exacerbations in Test group as compared to Placebo group. There was significant clinical improvement in Test group as compared to Placebo group. The Tinospora cordifolia group had better improvement in quality of life as compared to Placebo group.

\section{CONCLUSION}

Tinospora cordifolia reduces repeated infections, improves signs and symptoms, improves quality of life and also improve lung functions. So it can be given as adjuvant therapy in chronic bronchitis patients in addition to standard treatment.

\section{KEYWORDS}

Tinospora Cordifolia, Chronic Bronchitis.

HOW TO CITE THIS ARTICLE: Hannan A, Sinha S, Sinha R, et al. Effect of Tinospora cordifolia in chronic bronchitis patients. J. Evolution Med. Dent. Sci. 2017;6(23):1850-1857, DOI: 10.14260/Jemds/2017/408

\section{BACKGROUND}

Chronic obstructive pulmonary disease is one of the common problem affecting $10 \%$ of population above the age of 45 years in the world. ${ }^{1}$ This is associated with frequent acute medical admissions to hospital. These frequent acute exacerbations result in repeated hospitalisation, general disability and absence from work.

If properly not treated, patients may land into complications and contribute to significant morbidity and mortality. ${ }^{2}$ There is evidence to suggest that morbidity and mortality rates in COPD patients are rising and as such prompt and proper treatment of these patients is essential. ${ }^{3}$

Financial or Other, Competing Interest: None.

Submission 24-01-2017, Peer Review 24-02-2017,

Acceptance 03-03-2017, Published 20-03-2017.

Corresponding Author:

Dr. Abdul Hannan,

\#4/4, "Swastik" Building, Flat No. 4,

Sir J.J. Hospital Campus, Byculla, Mumbai-8.

E-mail: diabetes77@gmail.com

DOI: $10.14260 /$ jemds $/ 2017 / 408$

\section{(c) $(1) \odot$}

One of the factor contributing in incidences of repeated infections is suppressed immune response by host. The depression of immune system is characterised by a reduction in the number and phagocytic function of neutrophils and macrophages as well as a reduction in the intracellular bactericidal capacity of these cells. The T-cell function is also diminished. ${ }^{4}$

An attempt to overcome this problem has been made by introducing the concept of 'prohost' therapy. Several naturally occurring and synthetic substances like BCG, Corynebacterium parvum, muramyl dipeptide, glucans, interleukin- 1 and colony stimulating factors have been used to enhance the nonspecific host resistance against infections. However, these substances share several limitations, one of their major drawbacks is the necessity to administer them parenterally, another factor is the cost of the therapy.

Against this background, the potential of Indian medicinal plants to be useful as immunostimulants appears encouraging. 5 Ayurveda, the Indian traditional system of medicine, lays emphasis on promotion of health a similar concept to strengthening host defense against different 
diseases. These plants are labelled as 'Rasayanas,' Tinospora cordifolia is one of them. ${ }^{6}$

Tinospora cordifolia also known as Guduchi belongs to family menispermaceae. ${ }^{7}$ It is a large glabrous climber with succulent corks grooved stems. Tinospora cordifolia is claimed to be useful as a general tonic, diuretic, antipyretic, anti-inflammatory and aphrodisiac in Ayurveda. 8 Thattle UM and Dahanukar SA 1989 demonstrated immunostimulatory effect of Tinospora cordifolia. ${ }^{4}$

Present study was undertaken by Department of Pharmacology, Clinical Division, Govt. Medical College and Hospital, Aurangabad to evaluate Tinospora cordifolia's immunostimulatory effect in chronic bronchitis patients receiving standard drug therapy, parameters considered were-

- Reduction in episodes of acute exacerbations.

- Improvement in signs and symptoms clinically.

- Improvement in quality of life.

\section{Aims and Objectives}

1. To evaluate the efficacy of Tinospora cordifolia in improvement of signs and symptoms in patients with chronic bronchitis as an adjuvant to standard therapy.

2. To evaluate reduction in incidence of acute exacerbations in patients with chronic bronchitis by Tinospora cordifolia as an adjuvant to standard therapy.

3. To evaluate improvement in quality of life in patients with chronic bronchitis by Tinospora cordifolia as an adjuvant to standard therapy.

4. To evaluate improvement in pulmonary function test in patients with chronic bronchitis by Tinospora cordifolia as an adjuvant to standard therapy.

\section{MATERIALS AND METHODS}

Present study was conducted in Department of Pharmacology, Clinical Division, Government Medical College and Hospital, Aurangabad.

\section{Study Design}

Randomised, Single Blind, Placebo Controlled Study.

\section{Study Population \\ Sample Size}

Total 60 patients were enrolled in the study. These patients were randomly divided into two groups of 30 each.

\section{Inclusion Criteria}

Those included were diagnosed cases of chronic bronchitis between 18 to 70 years' age group.

\section{Exclusion Criteria}

Patients with complication like cor pulmonale and respiratory failure.

\section{Study Plan}

Patients were selected from O.P.D., Govt. Medical College and Hospital, Aurangabad. Patients were diagnosed as having chronic bronchitis and satisfying the inclusion criteria were enrolled in the study. After explaining all the details of study, actions and safety of drug, written consent was taken. Study was approved by Ethical Committee of Govt. Medical College and Hospital, Aurangabad. Patients were assigned to two groups of 30 each, (either Test or Placebo). Patients were randomly divided into groups.

Name, age and address of each patient was noted on case record form; personal history like smoking and alcohol was noted. Weight, temperature and blood pressure were recorded. Number of episodes of acute exacerbations in previous two months were recorded. Chief complaints and history regarding present illness was asked.

Symptoms like breathlessness, cough and expectoration were asked. Physical examination pertaining to respiratory systems was done. The severity of symptoms present at the time of enrollment was recorded independently in respect of each patient on a four-point scale (Absent, mild, moderate and severe) with qualifying norms given below.

\begin{tabular}{|c|c|c|}
\hline- & Absent & Symptoms Absent \\
\hline+ & Mild & $\begin{array}{r}\text { Symptoms Present, but no Interference } \\
\text { with Daily Activities }\end{array}$ \\
\hline++ & Moderate & $\begin{array}{c}\text { Symptoms Present and Some } \\
\text { Interference with Daily Activities }\end{array}$ \\
\hline+++ & Severe & Symptoms Present with Incapacitation \\
\hline
\end{tabular}

Also, total symptom score was arrived at by adding individual severity scores (each + mark was to be taken as 1 i.e. $+=1,++=2,+++=3$ ). On physical examination wheezing, respiratory sound and prolonged expiration was examined.

\section{Investigations}

The following baseline investigation was carried out prior to administration of study drugs.

1. Complete blood count.

2. Spirometry- Forced expiratory volume in $1 \mathrm{sec}$ (FEV-I), Peak Expiratory Flow (PEF).

\section{Followup}

Patients were followed up every 15 days. On each followup, drugs for next 15 days was given to patients. On each followup symptoms like cough, expectoration and breathlessness were asked. Physical examination was done.

Investigations like $\mathrm{CBC}$ and Spirometry was done at baseline after one month at the end of study.

\section{Spirometry}

Pulmonary function test was done on computerised Spirometry. Instrument used is called as spirometrics, which was made in USA.

\section{Force Expiratory Volume in One Second (FEV)}

FEV is performed during FVC maneuver.

\section{Procedure}

Patient is asked to take deep inspiration; as soon as inspiration ends patient has to expire completely into apparatus.

Amount of air expired in one second is considered as $\mathrm{FEV}_{\mathrm{h}}$, it is directly calculated by apparatus.

\section{Peak Expiratory Flow Rates (PEFR)}

PEFR is the maximum flow rate attainable any time during forced expiratory volume from the position of maximum inspiration. 


\section{Procedure}

Nostrils were closed with clamp, patient was asked to take a deep breath and blow the air in flow meter as fast as possible, it was recorded in litres per second.

\section{Quality of Life Assessment}

Quality of life was assessed at the baseline and every 15 days. Following were the parameters assessed.

\section{Able to Carry on Normal Activity and to Work, no Special Care is needed \\ i. Normal, no complaints, no evidence of disease $100 \%$. \\ ii. Able to carry on normal activity, minor signs or symptoms of disease $90 \%$. \\ iii. Normal activity with effort, some signs and symptoms of disease $80 \%$.}

Unable to Work. Able to Live at Homecare for Most Personal Needs. A Varying amount of Assistance is needed

i. Cares for self, unable to carry on normal activity or to do active work $70 \%$.

ii. Requires occasional assistance, but is able to care for most of his needs $60 \%$.

iii. Requires considerable assistance and frequent medical care $50 \%$.

Unable to Care for Self. Requires Equivalent of Institutional or Hospital Care. Disease may be Progressing Rapidly

i. Disabled, required special care and assistance $40 \%$.

ii. Severely disabled, hospitalisation is indicated although death not imminent 30\%.

iii. Very sick, hospitalisation necessary, active supportive treatment necessary $20 \%$.

\section{Moribund, fatal processes progressing rapidly $10 \%$,} Dead 0\%.

\section{Drug Administration}

Tablets

a. Film coated Tinospora cordifolia tablet contains $500 \mathrm{mg}$ of active ingredient. Tablets were dispensed in bottle containing 50 tablets. Each bottle was for 15 days therapy. Such 4 bottles were provided to each patient of Test group.

b. Palcebo tablets were identical looking packed in bottles. Each bottle contains 50 tablets. One bottle was provided for 15 days, such 4 bottles were provided to each patient of Palcebo group.

\section{Dosage}

\section{Test Group}

Tab. Tinospora cordifolia $500 \mathrm{mg}$ three times a day for a period of 8 weeks from the bottle assigned to him/her.

\section{Placebo Group}

Placebo tablets three times a day for a period of 8 weeks from the bottle assigned to him/her.

\section{Standard Therapy}

Acute exacerbations were treated with antibiotics, (Roxithromycin $150 \mathrm{mg}$ BD), Theophylline $200 \mathrm{mg}$ BD and
Asthalin rotahaler. Therapy was given up to the control of condition. Additional therapy like higher antibiotics and steroid therapy was needed for some patients to control acute attack.

\section{Evaluation}

Efficacy

Efficacy was compared on the Basis of-

i. Improvement in symptoms and sign judged by scoring every 15 days.

ii. Reduction in number of acute exacerbations during 8 weeks of study compared to previous 2 months.

iii. Improvement in quality of life judged by parameters mentioned.

iv. Improvement in pulmonary performance calculated by spirometry.

Safety

Safety of drug was recorded by noting side effects experienced by patients.

\section{Statistical Analysis}

Student's unpaired ' $t$ ' test applied for comparison between results of placebo and test group.

\begin{tabular}{|c|c|c|}
\hline Sl. No. & \multicolumn{2}{|c|}{ *Percentage of Prediction of Expected Value } \\
\hline & Baseline & At the End of Study \\
\hline 1 & 27 & 50 \\
\hline 2 & 16 & 33 \\
\hline 3 & 31 & 45 \\
\hline 4 & 25 & 30 \\
\hline 5 & 18 & 25 \\
\hline 6 & 30 & 41 \\
\hline 7 & 15 & 24 \\
\hline 8 & 17 & 25 \\
\hline 9 & 36 & 43 \\
\hline 10 & 27 & 40 \\
\hline 11 & 25 & 33 \\
\hline 12 & 32 & 47 \\
\hline 13 & 27 & 50 \\
\hline 14 & 30 & 50 \\
\hline 15 & 31 & 45 \\
\hline 16 & 31 & 47 \\
\hline 17 & 50 & 65 \\
\hline 18 & 27 & 26 \\
\hline 19 & 30 & 42 \\
\hline 20 & 32 & 46 \\
\hline 21 & 45 & 58 \\
\hline 22 & 42 & 51 \\
\hline 23 & 25 & 38 \\
\hline 24 & 32 & 46 \\
\hline 25 & 35 & 48 \\
\hline 26 & 45 & 56 \\
\hline 27 & 40 & 53 \\
\hline 28 & 20 & 21 \\
\hline 29 & 26 & 35 \\
\hline 30 & 39 & 48 \\
\hline Mean & 30.2 & $42.36 \pm 10.32$ \\
\hline $\begin{array}{r}T c \\
\text { Expirc }\end{array}$ & $\begin{array}{l}\text { le 1. Effect of Ti } \\
\text { ory Volume in } 1 \\
\text { Group in Ch. }\end{array}$ & $\begin{array}{l}\text { ordifolia on Force } \\
\text { of Spirometry in Test } \\
\text { is Patients }\end{array}$ \\
\hline
\end{tabular}

*Expected values of spirometry was calculated by computerised spirometry machine on the basis of factors affecting it. 


\begin{tabular}{|c|c|c|}
\hline Sl. No. & \multicolumn{2}{|c|}{ *Percentage of Prediction of Expected Value } \\
\hline & Baseline & At the End of Study \\
\hline 1 & 31 & 28 \\
\hline 2 & 25 & 25 \\
\hline 3 & 21 & 25 \\
\hline 4 & 22 & 39 \\
\hline 5 & 30 & 35 \\
\hline 6 & 25 & 32 \\
\hline 7 & 29 & 31 \\
\hline 8 & 26 & 27 \\
\hline 9 & 29 & 31 \\
\hline 10 & 28 & 30 \\
\hline 11 & 43 & 41 \\
\hline 12 & 33 & 36 \\
\hline 13 & 35 & 36 \\
\hline 14 & 28 & 29 \\
\hline 15 & 35 & 34 \\
\hline 16 & 28 & 29 \\
\hline 17 & 29 & 33 \\
\hline 18 & 43 & 46 \\
\hline 19 & 28 & 31 \\
\hline 20 & 30 & 36 \\
\hline 21 & 40 & 43 \\
\hline 22 & 33 & 35 \\
\hline 23 & 29 & 33 \\
\hline 24 & 35 & 38 \\
\hline 25 & 35 & 40 \\
\hline 26 & 35 & 41 \\
\hline 27 & 25 & 26 \\
\hline 28 & 40 & 42 \\
\hline 29 & 28 & 34 \\
\hline 30 & 22 & 23 \\
\hline Mean & 29.33 & $33.63 \pm 5.73$ \\
\hline Table 2 & $\begin{array}{l}\text { ffect of Tinospo } \\
\text { Group in } 1 \text { sec. }( \\
\text { Group in Ch }\end{array}$ & $\begin{array}{l}\text { lia on Force Expirator] } \\
\text { irometry in Test } \\
\text { is Patients }\end{array}$ \\
\hline
\end{tabular}

*Expected values of spirometry was calculated by computerised spirometry machine on the basis of factors affecting it.

\begin{tabular}{|c|c|c|}
\hline & Test Group & Placebo Group \\
\hline Mean & 42.36 & 33.63 \\
\hline S.D. & 10.32 & 5.73 \\
\hline 'T' value & \multicolumn{2}{|c|}{4.05} \\
\hline \multicolumn{2}{|c|}{${ }^{*} \mathrm{P}<0.05$} \\
\hline 'P' value & Table 3. Comparison of Force Expiratory Volume in \\
1 sec. (FEV) of Spirometry in Test and Placebo Group \\
in Ch. Bronchitis Patients \\
*Statistically significant
\end{tabular}

\begin{tabular}{|c|c|c|}
\hline Sl. No. & *Percentage of Prediction of Expected Value \\
\hline & Baseline & At the End of Study \\
\hline 1 & 14 & 31 \\
\hline 2 & 20 & 28 \\
\hline 3 & 22 & 36 \\
\hline 4 & 16 & 22 \\
\hline 5 & 11 & 19 \\
\hline 6 & 23 & 32 \\
\hline 7 & 13 & 20 \\
\hline 8 & 22 & 30 \\
\hline 9 & 19 & 25 \\
\hline 10 & 15 & 26 \\
\hline 11 & 16 & 23 \\
\hline 12 & 25 & 38 \\
\hline
\end{tabular}

\begin{tabular}{|c|c|c|}
\hline 13 & 18 & 31 \\
\hline 14 & 13 & 31 \\
\hline 15 & 20 & 36 \\
\hline 16 & 22 & 37 \\
\hline 17 & 37 & 47 \\
\hline 18 & 15 & 15 \\
\hline 19 & 20 & 30 \\
\hline 20 & 25 & 36 \\
\hline 21 & 34 & 44 \\
\hline 22 & 22 & 36 \\
\hline 23 & 25 & 36 \\
\hline 24 & 25 & 36 \\
\hline 25 & 31 & 41 \\
\hline 26 & 32 & 41 \\
\hline 27 & 25 & 31 \\
\hline 28 & 16 & 18 \\
\hline 29 & 18 & 32 \\
\hline 30 & 27 & 34 \\
\hline Mean & 21.36 & $30.7 \pm 8.37$ \\
\hline \multicolumn{2}{|c|}{ Table 4. Effect of Tinospora cordifolia on Peak } \\
Expiratory Flow (PEF) of Spirometry in Test Group \\
in Chronic Bronchitis Patients \\
\hline \multicolumn{2}{|c|}{} \\
\hline
\end{tabular}

*Expected value values of spirometry was calculated by computerised spirometry machine on the basis of factors affecting it.

\begin{tabular}{|c|c|c|}
\hline \multirow[t]{2}{*}{ Sl. No. } & \multicolumn{2}{|c|}{ *Percentage of Prediction of Expected Value } \\
\hline & Baseline & At the End of Study \\
\hline 1 & 25 & 22 \\
\hline 2 & 28 & 28 \\
\hline 3 & 12 & 15 \\
\hline 4 & 30 & 27 \\
\hline 5 & 29 & 31 \\
\hline 6 & 22 & 30 \\
\hline 7 & 22 & 25 \\
\hline 8 & 15 & 16 \\
\hline 9 & 22 & 2 \\
\hline 10 & 20 & 31 \\
\hline 11 & 29 & 25 \\
\hline 12 & 22 & 22 \\
\hline 13 & 25 & 27 \\
\hline 14 & 20 & 22 \\
\hline 15 & 29 & 27 \\
\hline 16 & 20 & 22 \\
\hline 17 & 22 & 25 \\
\hline 18 & 24 & 30 \\
\hline 19 & 20 & 23 \\
\hline 20 & 22 & 27 \\
\hline 21 & 23 & 26 \\
\hline 22 & 23 & 26 \\
\hline 23 & 22 & 25 \\
\hline 24 & 31 & 33 \\
\hline 25 & 21 & 27 \\
\hline 26 & 25 & 29 \\
\hline 27 & 15 & 17 \\
\hline 28 & 23 & 25 \\
\hline 29 & 20 & 25 \\
\hline 30 & 12 & 13 \\
\hline Mean & 22.43 & $24.53 \pm 4.58$ \\
\hline & $\begin{array}{c}\text { Pe 5. Effect of } \\
\text { piratory Flon } \\
\text { Group in }\end{array}$ & $\begin{array}{l}\text { a cordifolia on Peak } \\
\text { Spirometry in Test } \\
\text { hitis Patients }\end{array}$ \\
\hline
\end{tabular}

*Expected values of spirometry was calculated by computerised spirometry machine on the basis of factors affecting it. 


\begin{tabular}{|c|c|c|}
\hline & Test Group & Placebo Group \\
\hline Mean & 30.70 & 24.53 \\
\hline S.D. & 8.37 & 4.58 \\
\hline 'T'value & \multicolumn{2}{|c|}{3.54} \\
\hline 'P'value & \multicolumn{2}{|c|}{$* \mathrm{P}<0.05$} \\
\hline \multicolumn{3}{|c|}{$\begin{array}{c}\text { Table 6. Comparison of Force Expiratory Volume in } \\
1 \text { sec. (FEV) of Spirometry in Test and Placebo } \\
\text { Group in Ch. Bronchitis Patients }\end{array}$} \\
\hline
\end{tabular}

*Statistically significant

\begin{tabular}{|c|c|c|}
\hline Sl. No. & \multicolumn{2}{|c|}{ Number of Episodes } \\
\hline & Pretreatment* & During Treatment** \\
\hline 1 & 6 & 2 \\
\hline 2 & 7 & 2 \\
\hline 3 & 3 & 1 \\
\hline 4 & 2 & 1 \\
\hline 5 & 4 & 2 \\
\hline 6 & 3 & 2 \\
\hline 7 & 3 & 1 \\
\hline 8 & 2 & 2 \\
\hline 9 & 5 & 2 \\
\hline 10 & 5 & 2 \\
\hline 11 & 5 & 2 \\
\hline 12 & 5 & 2 \\
\hline 13 & 6 & 3 \\
\hline 14 & 5 & 2 \\
\hline 15 & 4 & 1 \\
\hline 16 & 5 & 2 \\
\hline 17 & 6 & 3 \\
\hline 18 & 6 & 3 \\
\hline 19 & 3 & 1 \\
\hline 20 & 5 & 2 \\
\hline 21 & 2 & 2 \\
\hline 22 & 6 & 3 \\
\hline 23 & 5 & 2 \\
\hline 24 & 5 & 4 \\
\hline 25 & 5 & 2 \\
\hline 26 & 5 & 2 \\
\hline 27 & 4 & 2 \\
\hline 28 & 5 & 2 \\
\hline 29 & 3 & 2 \\
\hline 30 & 5 & 3 \\
\hline Mean & 4.50 & $2.06 \pm 0.41$ \\
\hline
\end{tabular}

*Episodes in previous two months before starting treatment. **Episodes during two months of study.

\begin{tabular}{|c|c|c|}
\hline Sl. No. & \multicolumn{2}{|c|}{ Number of Episodes } \\
\hline & Pretreatment* $^{*}$ & During Treatment** \\
\hline 1 & 6 & 4 \\
\hline 2 & 5 & 4 \\
\hline 3 & 5 & 4 \\
\hline 4 & 4 & 4 \\
\hline 5 & 3 & 3 \\
\hline 6 & 4 & 4 \\
\hline 7 & 5 & 4 \\
\hline 8 & 3 & 4 \\
\hline 9 & 5 & 4 \\
\hline 10 & 4 & 4 \\
\hline 11 & 3 & 3 \\
\hline 12 & 3 & 4 \\
\hline 13 & 4 & 4 \\
\hline 14 & 5 & 4 \\
\hline
\end{tabular}

\begin{tabular}{|c|c|c|}
\hline 15 & 6 & 5 \\
\hline 16 & 3 & 3 \\
\hline 17 & 3 & 3 \\
\hline 18 & 3 & 4 \\
\hline 19 & 4 & 4 \\
\hline 20 & 3 & 2 \\
\hline 21 & 5 & 4 \\
\hline 22 & 4 & 4 \\
\hline 23 & 5 & 5 \\
\hline 24 & 5 & 4 \\
\hline 25 & 5 & 4 \\
\hline 26 & 4 & 4 \\
\hline 27 & 6 & 4 \\
\hline 28 & 4 & 4 \\
\hline 29 & 5 & 4 \\
\hline 30 & 6 & 5 \\
\hline Mean & 4.33 & $3.9 \pm 0.79$ \\
\hline \multicolumn{2}{|c|}{ Table 8. Effect of Tinospora cordifolia on Peak Expiratory } \\
FEF) of Spirometry in Test Group \\
in Ch. Bronchitis Patients \\
\hline
\end{tabular}

*Episodes in previous two months before starting treatment. **Episodes during two months of study.

\begin{tabular}{|c|c|c|}
\hline & Test Group & Placebo Group \\
\hline Mean & 2.06 & 3.90 \\
\hline S.D. & 0.41 & 0.76 \\
\hline 'T'value & \multicolumn{2}{|c|}{11.86} \\
\hline \multicolumn{2}{|c|}{${ }^{2} \mathrm{P}<0.05$} \\
\hline \multicolumn{2}{|c|}{$\mathrm{P}^{\prime}$ value } & \multicolumn{2}{|c|}{ 9. Comparison of Reduction in Incidence of } \\
Episodes of Acute Exacerbations in Test and Placebo \\
Group in Ch. Bronchitis Patients \\
\hline
\end{tabular}

*Statistically significant

\begin{tabular}{|c|c|c|}
\hline \multirow[t]{2}{*}{ Sl. No. } & \multicolumn{2}{|c|}{\begin{tabular}{|l} 
Percentage Score \\
\end{tabular}} \\
\hline & Baseline & After 2 Months \\
\hline 1 & 0 & 75 \\
\hline 2 & 0 & 50 \\
\hline 3 & 25 & 75 \\
\hline 4 & 0 & 75 \\
\hline 5 & 25 & 75 \\
\hline 6 & 0 & 75 \\
\hline 7 & 0 & 75 \\
\hline 8 & 0 & 75 \\
\hline 9 & 0 & 75 \\
\hline 10 & 0 & 75 \\
\hline 11 & 0 & 50 \\
\hline 12 & 0 & 50 \\
\hline 13 & 0 & 50 \\
\hline 14 & 25 & 75 \\
\hline 15 & 0 & 75 \\
\hline 16 & 0 & 75 \\
\hline 17 & 0 & 50 \\
\hline 18 & 0 & 25 \\
\hline 19 & 0 & 75 \\
\hline 20 & 0 & 75 \\
\hline 21 & 25 & 75 \\
\hline 22 & 0 & 75 \\
\hline 23 & 0 & 75 \\
\hline 24 & 0 & 75 \\
\hline 25 & 0 & 75 \\
\hline 26 & 0 & 50 \\
\hline 27 & 0 & 50 \\
\hline 28 & 0 & 25 \\
\hline 29 & 0 & 50 \\
\hline 30 & 0 & 75 \\
\hline
\end{tabular}




\begin{tabular}{|c|c|c|}
\hline Mean & 3.33 & $65 \pm 15.27$ \\
\hline Table 10. Effect of Tinospora cordifolia on Peak \\
Expiratory Flow (PEF) of Spirometry in Test Group \\
in Ch. Bronchitis Patients
\end{tabular}

\begin{tabular}{|c|c|c|}
\hline \multirow[t]{2}{*}{ Sl. No. } & \multicolumn{2}{|c|}{$\begin{array}{l}\text { Percentage Score } \\
\end{array}$} \\
\hline & Baseline & After 2 Months \\
\hline 1 & 0 & 25 \\
\hline 2 & 0 & 25 \\
\hline 3 & 0 & 25 \\
\hline 4 & 0 & 50 \\
\hline 5 & 0 & 0 \\
\hline 6 & 0 & 25 \\
\hline 7 & 0 & 25 \\
\hline 8 & 0 & 25 \\
\hline 9 & 0 & 25 \\
\hline 10 & 25 & 25 \\
\hline 11 & 0 & 25 \\
\hline 12 & 0 & 25 \\
\hline 13 & 0 & 25 \\
\hline 14 & 0 & 25 \\
\hline 15 & 0 & 0 \\
\hline 16 & 0 & 25 \\
\hline 17 & 0 & 25 \\
\hline 18 & 0 & 25 \\
\hline 19 & 0 & 25 \\
\hline 20 & 25 & 75 \\
\hline 21 & 0 & 50 \\
\hline 22 & 25 & 25 \\
\hline 23 & 0 & 25 \\
\hline 24 & 0 & 50 \\
\hline 25 & 0 & 25 \\
\hline 26 & 25 & 25 \\
\hline 27 & 0 & 50 \\
\hline 28 & 0 & 25 \\
\hline 29 & 25 & 50 \\
\hline 30 & 0 & 25 \\
\hline Mean & 4.16 & $29.16 \pm 14.55$ \\
\hline $\begin{array}{r}T a b \\
E x\end{array}$ & $\begin{array}{l}\text { tof Tinos } \\
\text { low (PEF) } \\
\text { in Ch. Bro }\end{array}$ & $\begin{array}{l}\text { lifolia on Peak } \\
\text { netry in Test } \\
\text { atients }\end{array}$ \\
\hline
\end{tabular}

\begin{tabular}{|c|c|c|}
\hline & Test Group & Placebo Group \\
\hline Mean & 65.00 & 29.16 \\
\hline S.D. & 15.27 & 14.55 \\
\hline 'T' value & \multicolumn{2}{|c|}{9.30} \\
\hline 'P' value & \multicolumn{2}{|c|}{${ }^{2}<0.05$} \\
\hline
\end{tabular}

Table 12. Comparison of Clinical Assessment in Test and Placebo Group in Ch. Bronchitis Patients

*Statistically significant

\begin{tabular}{|c|c|c|}
\hline Sl. No. & \multicolumn{2}{|c|}{ Percentage Score } \\
\hline & Baseline & After 2 Months \\
\hline 1 & 50 & 90 \\
\hline 2 & 50 & 80 \\
\hline 3 & 60 & 90 \\
\hline 4 & 50 & 90 \\
\hline 5 & 60 & 90 \\
\hline 6 & 70 & 90 \\
\hline 7 & 50 & 80 \\
\hline 8 & 70 & 90 \\
\hline 9 & 60 & 90 \\
\hline 10 & 50 & 80 \\
\hline
\end{tabular}

\begin{tabular}{|c|c|c|}
\hline 11 & 50 & 80 \\
\hline 12 & 50 & 80 \\
\hline 13 & 70 & 90 \\
\hline 14 & 60 & 90 \\
\hline 15 & 70 & 90 \\
\hline 16 & 50 & 90 \\
\hline 17 & 50 & 80 \\
\hline 18 & 40 & 50 \\
\hline 19 & 60 & 90 \\
\hline 20 & 50 & 80 \\
\hline 21 & 50 & 80 \\
\hline 22 & 50 & 80 \\
\hline 23 & 50 & 70 \\
\hline 24 & 50 & 80 \\
\hline 25 & 50 & 80 \\
\hline 26 & 50 & 80 \\
\hline 27 & 50 & 80 \\
\hline 28 & 50 & 60 \\
\hline 29 & 50 & 70 \\
\hline 30 & 50 & 70 \\
\hline Mean & 51.66 & $81.33 \pm 9.56$ \\
\hline
\end{tabular}

Table 13. Assessment of Effect of Tinospora cordifolia on Quality of Life in Test Group in Ch. Bronchitis

\begin{tabular}{|c|c|c|}
\hline Sl. No. & \multicolumn{2}{|c|}{ Percentage Score } \\
\hline & Baseline & After 2 Months \\
\hline 1 & 60 & 70 \\
\hline 2 & 70 & 80 \\
\hline 3 & 70 & 80 \\
\hline 4 & 50 & 60 \\
\hline 5 & 50 & 70 \\
\hline 6 & 40 & 60 \\
\hline 7 & 40 & 50 \\
\hline 8 & 40 & 50 \\
\hline 9 & 50 & 60 \\
\hline 10 & 50 & 70 \\
\hline 11 & 50 & 70 \\
\hline 12 & 50 & 60 \\
\hline 13 & 50 & 60 \\
\hline 14 & 50 & 60 \\
\hline 15 & 50 & 50 \\
\hline 16 & 50 & 60 \\
\hline 17 & 50 & 60 \\
\hline 18 & 50 & 60 \\
\hline 19 & 50 & 60 \\
\hline 20 & 50 & 80 \\
\hline 21 & 50 & 60 \\
\hline $22^{\prime}$ & 50 & 60 \\
\hline 23 & 50 & 60 \\
\hline 24 & 50 & 60 \\
\hline 25 & 50 & 60 \\
\hline 26 & 50 & 60 \\
\hline 27 & 50 & 80 \\
\hline 28 & 50 & 60 \\
\hline 29 & 50 & 70 \\
\hline 30 & 50 & 60 \\
\hline Mean & 50.66 & $63 \pm 8.22$ \\
\hline
\end{tabular}

Table 14. Assessment of Effect of Tinospora cordifolia on Quality of Life in Placebo Group in Ch. Bronchitis Patients 


\begin{tabular}{|c|c|c|}
\hline & Test Group & Placebo Group \\
\hline Mean & 81.33 & 63.00 \\
\hline S.D. & 9.56 & 8.22 \\
\hline 'T' value & \multicolumn{2}{|c|}{7.96} \\
\hline 'P' value & \multicolumn{2}{|c|}{${ }^{*}<0.05$} \\
\hline Table 15. Comparison of Quality of Life in Test and \\
Placebo Group in Ch. Bronchitis Patients
\end{tabular}

*Statistically significant

\section{RESULTS}

\section{Table 1, 2, 3}

Shows effect of Tinospora Cordifolia on Force Expiratory Volume in one sec, of spirometry in test and placebo group in chronic bronchitis patients. There is statistically significant ( $\mathrm{P}$ $<0.05$ ) increase in percentage of predicted values in test group as compared to Placebo group.

\section{Table 4, 5, 6}

Shows effect of Tinospora cordifolia on Peak Expiratory Flow of Spirometry in Test and Placebo group in chronic bronchitis patients. There is statistically significant $(\mathrm{P}<0.05)$ increase in percentage of prediction values in Test group as compared to Placebo group.

\section{Table 7, 8, 9}

Shows effect of Tinospora cordifolia on reduction of episodes of acute exacerbations in Test and Placebo group. There is statistically significant $(\mathrm{P}<0.05)$ reduction in episodes of acute exacerbations in Test group as compared to Placebo group.

\section{Table 10, 11, 12}

Shows effect of Tinospora cordifolia on clinical improvement in Test and Placebo group. There is statistically significant $(\mathrm{P}$ $<0.05$ ) improvement clinically in Test group as compared to Placebo group.

\section{Table 13, 14, 15}

Shows effect of Tinospora cordifolia on quality of life in test and placebo group. There is statistically significant $(\mathrm{P}<0.05)$ improvement in quality of life Test group as compared to Placebo group.

\section{DISCUSSION}

A number of plants and formulations have been reported in Ayurveda for their use in treatment of immune deficiency diseases in the last 2 or 3 decades. ${ }^{9}$ Some of them have been screened and tested for their efficiency. The results of such experimental works have revealed a clear picture of pharmacological activity. ${ }^{10,11}$ Tinospora cordifolia has been evaluated for its activity and found to possess potent immunomodulatory activity by various workers. ${ }^{12,13}$

Thatte U M showed Tinospora cordifolia has been found to induce leukocytosis, ${ }^{14,15}$ improve phagocytosis and intracellular killing capacity of neutrophils ${ }^{16,17}$ and macrophages. ${ }^{18}$ Dahanukar S A and Thatte U M demonstrated Tinospora cordifolia induces T-lymphocyte proliferation and increases cytokine secretion, such as interleukin-1 and interleukin-2 and Granulocyte Macrophage-Colony
Stimulating Factor (GM-CSF). ${ }^{19}$ Sainis K B showed that T.C. contains polyclonal B. cell activators when resulted in Blymphocytes proliferation and Mathew et al demonstrated enhanced antibody synthesis.

Kapil A and Sharma S demonstrated anticomplementary activity and serum opsonising activity.

Tinospora cordifolia extensively studied in patients with obstructive jaundice, cirrhosis, H. pylori infection, pulmonary tuberculosis, chronic asthma, abdominal sepsis and $\mathrm{K}$. pneumonia injection. It has given better results in the form of early improvement, reduction in repeated infection and prevention of complications.

In present study when Tinospora cordifolia was studied in chronic bronchitis patients, results obtained showed improvement in symptoms like breathlessness, cough, expectoration and wheeze in Test group as compared to Placebo group, which was statistically significant $(\mathrm{P}<0.05)$.

When quality of life was compared in Test and Placebo group in the form of - 1) Whether able to carry out normal activity and no special care is needed, 2) Able to live at home with assistance and 3) Unable to care for self and requires hospital care. Results showed improvement in quality of life in Test group statistically significant as compared to Placebo group $(\mathrm{P}<0.05)$. Above results are in consistent with studies of previous workers.

In the study, incidence of episodes of acute exacerbations during study was compared with episodes of acute exacerbations in previous two months before starting study. Results indicate statistically significant reduction in incidence of episodes of acute exacerbations in Test group as compared to Placebo group $(\mathrm{P}<0.05)$.

When values of Pulmonary Function Test in the form of Forced Expiratory Volume in one second (FEV-I) and Peak Expiratory Flow (PEF) were compared, there was statistically significant increase in Test group as compared to Placebo group. Though statistically significant increase in value of FEV-1 and PEF were there, values did not reach the normal levels as airway obstruction in chronic bronchitis remain irreversible. This rise may be due to anti-inflammatory action, reduction in episodes of exacerbation and increased alveolar macrophage function by Tinospora cordifolia. Tinospora cordifolia was well tolerated and no side effects were reported.

\section{CONCLUSION}

To conclude in present study, Tinospora cordifolia reduces repeated infections, improves signs and symptoms, improves quality of life and also improve lung functions. So it can be given as adjuvant therapy in chronic bronchitis patients in addition to standard treatment.

\section{REFERENCES}

[1] Antony S, Douglas S, Gordem L. Chronic bronchitis and emphysema. In: Corftan, Douglas. Respiratory diseases. 4th edn. Delhi: Oxford University Press 1993:490-526.

[2] Eric G, Honig RH. Chronic bronchitis, emphysema and airway obstruction. Harrisons Principles of Internal Medicine. 15th edn. McGraw Hills 2000;2:1491-5.

[3] Aggarwal AN, Gupta D. Management of chronic obstructive airways disease. Drugs Bulletin 1998;22(3):30-48. 
[4] Thattet UM, Dahanukar SA. Immunotherapeutic modification of experimental infections by Indian medicinal plants. Phytotherapy Research 1989;3(2):43-9.

[5] Kapil A, Sharma S. Immuno potentiating compounds from Tinospora cordifolia. Journal of Ethnopharmacology 1997;58(2):89-95.

[6] Atal CK, Sharma ML, Kaul A, et al. Immunomodulating agents of plant origin. I: Preliminary screening. Journal of Ethnopharmacology 1986;18(2):133-41.

[7] Dahanular SA, Thattle UM, Rege NM. Immunostimulants in Ayurveda medicine. In: Wagner H. edr. Immuno modulatory agents from plants. Basel, Switzerland: Birkhauser Verlag 1999:289-323.

[8] Dahanukar SA, Thatte UM. Current status of ayurveda in phytomedicine. Phytomedicine 1997;4(4):359-68.

[9] Kirtikar, Basu NO. Menispermacae. Indian medicinal plants. 4th edn. 1997:76-81.

[10] Arya VA, Vaiday S. Tinospora Cordifolia (wild). In: Miers ex Hook F, Thomas. Text book of Indian medicinal plants. 4th edn. 1997;5:283-9.

[11] Sharma PV, Guduchi. Classical uses of medicinal plants. 2nd edn. 1996:128-32.
[12] Cains IF. Tinospora Cordiofolia. The medical \& poisonous plants of India. 4th edn. 1994:175-6.

[13] Basu BD. Tinospora Cordifolia. In: Miers. edr. Text book of Indian medicinal plants. 4th edn. 1995:35-8.

[14] Rastogi RM, Mehrotra P. Tinospora (Menispermacae). Compendium of Indian medicinal plants. 3rd edn. 1990;2:679-80.

[15] Rughunathan K, Mitra R. Tinospora Cordifolia. In: Guduchi. Pharamacognosy of indigenous drugs. New Delhi: Central Council for Research in Ayurveda \& Siddha. 1982;1:321-53.

[16] Sharma DNK, Khosa RL. Chemistry and pharmacology of Tinosporacordifolia. In: Miers. Indian drugs. 1993;30(11):549.

[17] Atal CK, Kapur BM. Tinosporacordifolia. Cultivation and utilization of medical plants. 1st edn. 1977:2-10.

[18] Rege NN, Dahanukar SA. Quantitation of mircobicidal activity of mononuclear phagocytes: an invitro technique. Journal of Postgraduate Med 1993;39(1): 22-5.

[19] Thatte UM, Rao SG, Dahanukar SA. Tinospora cordifolia induces colony stimulating activity in serum. Journal of Postgraduate Med 1994; 40(4):202-3. 